\title{
Plant Use on Urban Roads within the Scope of Streetscape: Zonguldak Case Study
}

\author{
Canan Cengiz \\ Bartin University, Faculty of Engineering, Architecture and Design, Department of Landscape \\ Architecture, Bartin, Turkey. \\ E-mail: canancengiz@bartin.edu.tr \\ Deniz Karaelmas \\ Bulent Ecevit University, Caycuma Vocational School of Food and Agriculture, Zonguldak, Turkey \\ E-mail: deniz.karaelmas@beun.edu.tr \\ Aybuke Ozge Boz (Corresponding author) \\ Bartin University, Faculty of Engineering, Architecture and Design, Department of Landscape \\ Architecture, Bartin, Turkey. \\ E-mail: aboz@bartin.edu.tr
}

\begin{abstract}
Planted urban roads as an important component of urban landscape comprise the framework of urban open-green spaces. Planting of streets, boulevards and refuges which hold an important position among urban open-green spaces make undisputable ecological, aesthetic and functional contributions to the urban environment. The route on the Milli Egemenlik Street between the 100.Y1l Bus Terminal and Bülent Ecevit University 15 Temmuz Şehitler Campus located at the city of Zonguldak in Western Black Sea Region of Turkey was designated as the study area within the scope of this study. The plants used in the area were determined within the scope of the study along with road typologies and current physical states which were determined by way of on-site observations and photographs. Aesthetic, ecological and functional evaluations were made at the study area regarding plant use within the scope of streetscape.
\end{abstract}

Keywords: Zonguldak, Streetscape, Street planting, Road typology, Urban landscape

DOI: $10.7176 / \mathrm{JSTR} / 5-12-34$

\section{Introduction}

Road and square plantation in the city along with other green accompanying elements make up the urban open and green spaces (Yllmaz and Aksoy, 2009). Streets, boulevards and refuges are important open and green spaces that urbanites use or may use in their daily lives either with a vehicle or on foot (Küçük and Gül, 2005).

Roads make up the skeleton of the city for properly planned cities and they determine the direction for urban development. The entrances of cities are especially the most prestigious areas. Urban road trees are especially important with regard to the first impressions of those who visit the city for the first time (Aslanboğa, 1986; Karakaya and Zülfikar, 2013). Architectural structures in a city, open-green spaces and their relations represent the general characteristic of that city (Gül and Küçük, 2001).

Urban street plantation is the process of planting the suitable trees that will make aesthetic and functional contributions to refuges along or in the middle of vehicle roads or pedestrian walkways (Küçük and Gül, 2005). In addition to the physical, climatic, edaphic conditions of the region, the socio-economic structures and facilities of the cities are also effective on urban street plantation (Aslanboğa, 1986; Küçük and Gül, 2005).

According to LAEC (2007), Jim and Chen (2008), Ignatieva et al. (2010), Dawe (2011); There are significant opportunities that streets provide regarding the increase in the density of trees in the already present urban fabric especially in densely built-up inner cities (Tiwary et al., 2016). According to Pauleit (2003), Roy et al. (2012), Vlachokostas et al. (2014); It is especially useful to plant trees along streetscapes with regard to improving urban health and well-being especially in densely populated innercity built environments characterized by space constraints and high levels of pollution (Tiwary et al., 
2016).

Streets, boulevards, junctions and refuges comprising the transportation system in the city as a whole are inevitable usage areas as well as important public spaces that meet the active or passive recreation demands of people (Ertin et al., 2011). According to Pandit et al. (2013), Salmond et al. (2013); the studies carried out put forth that the public and special characteristics of trees planted on streets make positive contributions with regard to the advancement and sustainability of neighborhood tradition (Tiwary et al., 2016). Road trees as an important part of urban design have direct impacts on urban image (Zhou et al., 2012).

Plantation on urban roads have many advantages such as positive psychological and physical impacts on people (Turner-Skoff and Cavender, 2019), establishment of traffic safety, noise control, contribution of visual value and urban climate, reducing of air pollution, contributing to biological diversity and forming a habitat (McPherson, 2003; Samara and Tsitsoni, 2011; Yang et al. 2012). Trees are also important in the urban ecosystem for water management (Berland et al., 2017).

According to Kendal et al. (2012); Tree densities in cities such as Melbourne, Australia and Guangzhou, China are reported to reach up to $158-300$ strands per $\mathrm{km}$ of streets respectively which make up a significant amount of green space comprised of street plantation (Tiwary et al., 2016). Roads are man made urban corridors that make up a significant portion of the urban green infrastructure (Ranta et al., 2015). The streets, boulevards and refuges in cities are the most important open green spaces for recreational use by urbanites in addition to serving for vehicular or pedestrian transportation. Pedestrian and vehicle safety is also attained by way of planting designs on roads that connect various urban areas and means of use in addition to aesthetic and functional contributions (Sağlık, 2012) (Table 1).

Table 1. Expected Benefits from Roadside Trees (Ode, 2003)

\begin{tabular}{|l|l|}
\hline Benefits of Trees & Explanations \\
\hline Ensuring Traffic Safety & $\begin{array}{l}\text { Making the road more visible, preventing reflections of light, } \\
\text { separating vehicle-pedestrian spaces, making pedestrian activities } \\
\text { simpler. }\end{array}$ \\
\hline Developing of Visual Value & $\begin{array}{l}\text { Livening up of the monotonous appearance of cities by putting forth } \\
\text { the primary and auxiliary principles in design by way of color, shape } \\
\text { and texture, establishing space and balance. }\end{array}$ \\
\hline $\begin{array}{l}\text { Improving the Psychology } \\
\text { of Urbanites }\end{array}$ & $\begin{array}{l}\text { Moving urbanites closer to nature, increasing efficiency at work, } \\
\text { renewing joy of life, instilling a feeling of safety in pedestrians. }\end{array}$ \\
\hline $\begin{array}{l}\text { Arrangement of Urban } \\
\text { Climate }\end{array}$ & $\begin{array}{l}\text { Decreasing high temperatures via shading, balancing out of relative } \\
\text { humidity, preventing, the formation of wind corridors, etc. }\end{array}$ \\
\hline $\begin{array}{l}\text { Reducing Environmental } \\
\text { Pollution }\end{array}$ & $\begin{array}{l}\text { Masking of visual pollution, elimination of pollution due to traffic (Pb, } \\
\text { NOx, Cd, Ni, et al.), reducing of particles in the air. }\end{array}$ \\
\hline Reducing Noise & Absorbing traffic related noise thus reducing noise pollution. \\
\hline Other & Forming the urban green infrastructure system. \\
\hline
\end{tabular}

Road typology was determined for the route on the Milli Egemenlik Street between 100.Y1l Bus Terminal and Bülent Ecevit University 15 Temmuz Şehitler Campus selected as the study area. The plants used for urban street plantation have been subject to aesthetic, ecological and functional assessment within the scope of streetscape.

\section{Material}

Zonguldak is a city in Western Black Sea Region with coastline along the Black Sea to the west and north. Zonguldak is surrounded by Black Sea to the north, Bartın to the northeast, Karabük to the east, Bolu to the south and Düzce to the west (URL-1) (Figure 1). 


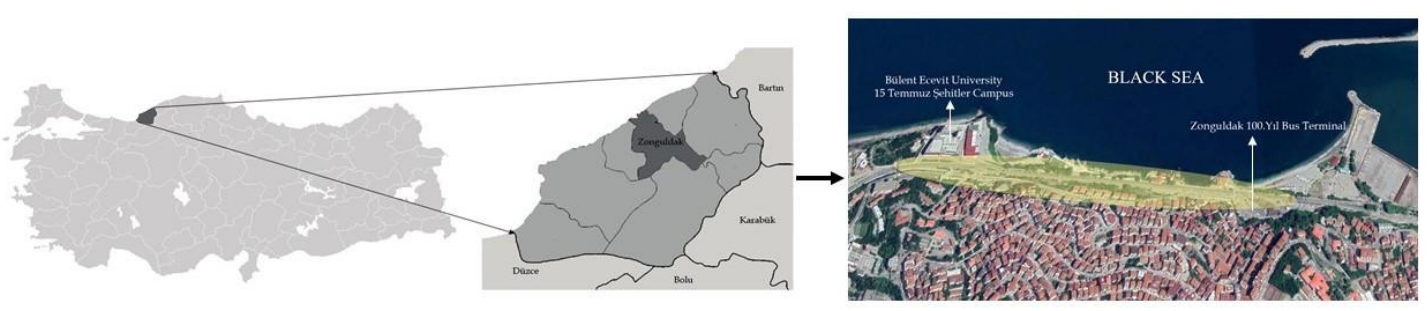

Figure 1. Location of Zonguldak province and study area

The city of Zonguldak has Black Sea climate (URL-2). Annual average temperature of Zonguldak province is 13.9 (URL-3). Average annual rainfall is $1250 \mathrm{~mm}$ and every season is rainy. The amount of rainfall decreases from the coast inwards. $65 \%$ of the city of is covered with forests and shrubbery, $32 \%$ with planted-cultivated areas, $3 \%$ with meadows and pastures (URL-2).

The study area is located on the Zonguldak-Bartın Highway between the Zonguldak Provincial Center and Kozlu Town and is known as "Milli Egemenlik Street". The study area covers the $1.2 \mathrm{~km}$ long route between the 15 Temmuz Şehitler Campus of Bülent Ecevit University and 100.Y1l Bus Terminal. There is a shopping mall, hotel, restaurants, coastal recreation areas and Istanbul Park along the coastal road.

\section{Method}

The study method is comprised of 4 stages: national and international literature survey was carried out during the first stage. On-site observations and examinations were carried out for the study area during the second stage for determining the plant species along the central refuge and roadsides. In addition, photographs were taken to be used in the study. Plant inventory list was prepared during the third stage of the study. Afterwards, the typology of the road was drawn using Photoshop CS5 software for putting forth its characteristics in the light of the acquired data. Plant use was evaluated with regard to its aesthetic, ecological and functional characteristics within the scope of streetscape during the final stage and suggestions were developed. Field study was carried out during the fall season and the general/complete properties of the evaluated plant species were considered instead of seasonal properties.

\section{Evaluation}

The plants used for road plantation (Table 3) within the scope of 3 different road typologies (Figure 2, Table 2) related with the $1.2 \mathrm{~km}$ section of Milli Egemenlik Street selected as the study area were evaluated aesthetically, ecologically and functionally within the scope of streetscape. The green band separating the vehicle road from the walkway, plant use on the walkway and refuge plantation were taken into consideration for the study area within the scope of streetscape. The areas limiting the width of the road outside the vehicle road and walkway width were not taken into consideration for Milli Egemenlik Street.

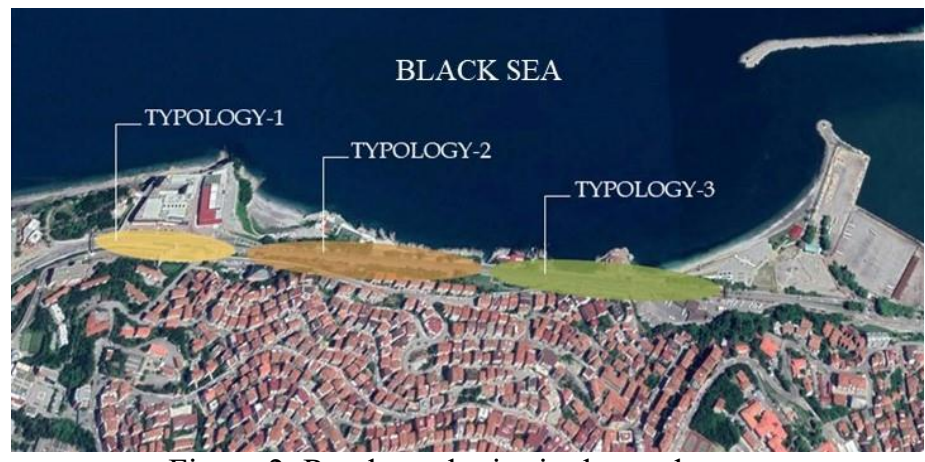

Figure 2. Road typologies in the study area 
Table 2. Road typologies and general characteristics of the road

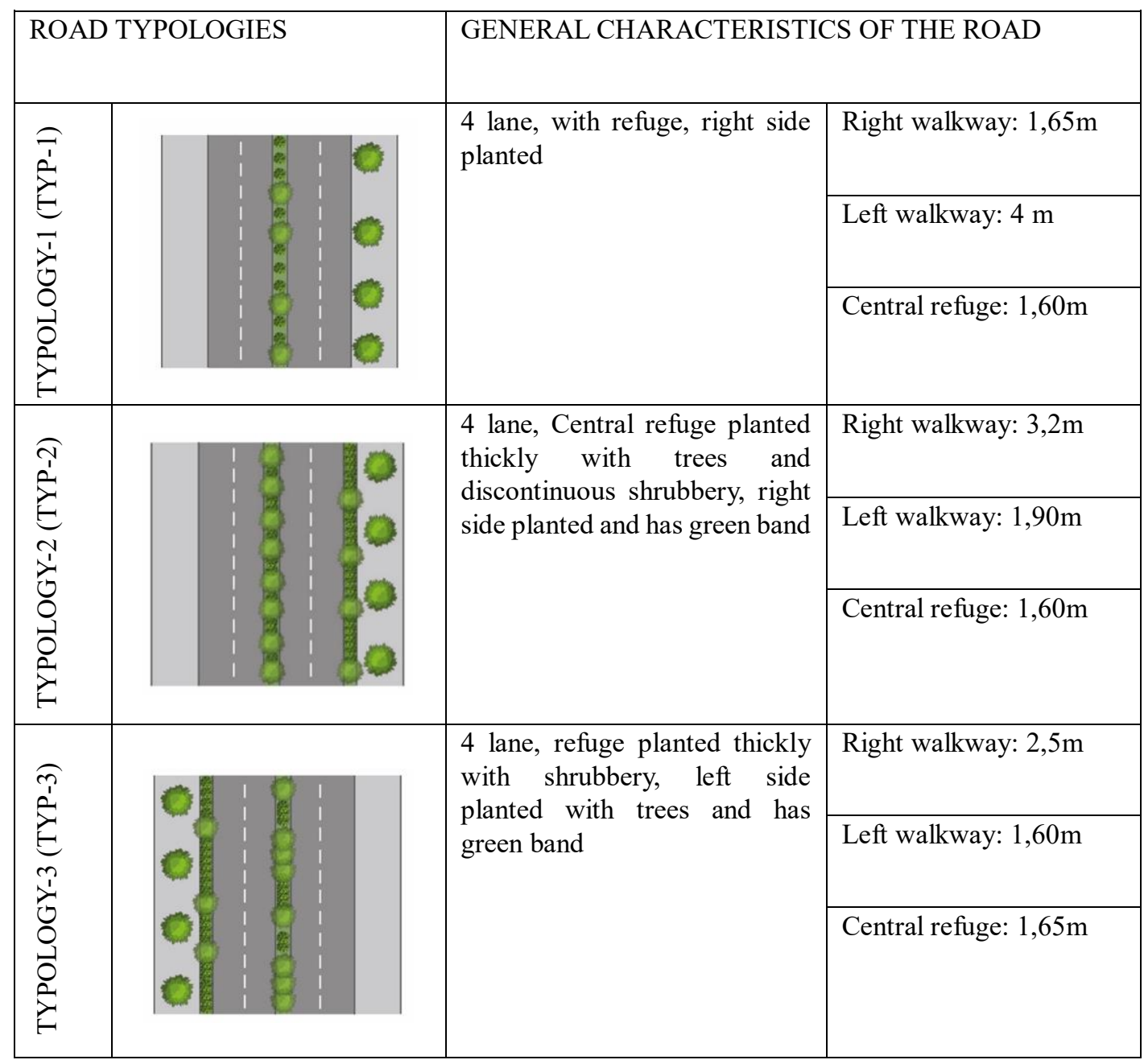

The section of the study area defined as "TYP-1" between the starting point in the western direction starting from the Bülent Ecevit University 15 Temmuz Şehitler Campus reference point has 4 lanes with refuge and the right side has been planted. The section of the urban green area system as part of the urban green area system evaluated as TYP-1 makes partly contributions the city of Zonguldak and its environmental aesthetics with regard to central refuge design and roadside plantation. Plant use in the section of the study area indicated as TYP-1 has not separated the pedestrian walkway and vehicle roads distinctively in terms of quality and quantity. Moreover, the use of plants has weak impacts with regard to direction and the formation of transportation corridor. The use of sporadically frequent and sparse shrubbery on the central refuge does not display a consistent positive characteristic for the prevention of headlights from the opposite lane with regard to traffic safety and the reduction of the severity of possible accidents. It also does not have deterrent effects with regard to pedestrian safety when crossing the streets outside pedestrian crossings. TYP-1 within the scope of roadside plantation application as one of the important components of streetscape provides insufficient spatial characteristics regarding pedestrian comfort on the whole streetscape with plantation application in only one of the walkways.

"TYP-2 positioned as an extension of TYP-1" the typology characteristics of which are determined from the perspective of the Bülent Ecevit University 15 Temmuz Şehitler Campus reference point which is also the starting point of the study area in the western direction is comprised of a route on which road side and central refuge design vary. TYP-2 has 4 lanes, a central refuge and is planted with thick trees and discontinuous shrubbery. The walkway on the right hand side of the road has been planted and a green band has been used between the vehicle road and the walkway. It makes significant contributions to the city of Zonguldak and its environmental aesthetics with regard to central refuge design and roadside plantation. Plant use in the section of the study area entitled as TYP-2 has linearly divided the vehicle road and walkway with only the green band application on the right walkway. It was observed to make 
positive impacts only in the Zonguldak-Bartın direction when plant use was examined with regard to direction and establishment of a transportation corridor. The use of trees and shrubbery in the central refuge were evaluated as a positive feature for the prevention of headlights from the opposite lane and the reduction of the severity of possible accidents. It also has deterrent effects with regard to pedestrian safety when crossing the streets outside pedestrian crossings. The green band application between the vehicle road and the walkway has also been evaluated positively with regard to pedestrian safety. TYP2 provides insufficient spatial characteristics for pedestrian comfort as part of streetscape with plantation application in only one of the walkways within the scope of roadside plantation application as one of the important components of streetscape.

Table 3. List of plants present in refuges, green bands and walkways

\begin{tabular}{|c|c|}
\hline GROUP OF TREES AND SHRUBS & GROUP OF SHRUBBERY \\
\hline Platanus sp. & Euonymuıs japonicus 'Mediopictus' \\
\hline Robinia pseudoacacia 'Umbraculifera' & Standard Roses \\
\hline Robinia $x$ margaretta 'Pink Cascade' & Nerium oleander \\
\hline Cupressocyparis leylandii & Meilland roses \\
\hline Archontophoenix sp. & Berberis thunbergii 'Atropurpurea' \\
\hline Magnolia grandiflora 'Gallisoniensis' & Euryops Pectinatus \\
\hline Picea pungens & Parthenocissus quinguefolia \\
\hline Cupressus arizonica & Yucca filamentosa 'Variegata' \\
\hline Pinus strobus L. & Chaenomeles japonica \\
\hline Cedrus deodora & Cotoneaster horizontalis \\
\hline Cedrus atlantica & Euonymuis pulchellus \\
\hline Aesculus hippocastanum & Forsythia $x$ intermedia \\
\hline Salix babylonica & Abelia $x$ grandiflora \\
\hline Morus nigra 'Pendula' & Juniperus chinensis 'Blue Alps' \\
\hline Phoenix canariensis & Albizia julibrissin \\
\hline Cupressus macrocarpa 'Gold Crest' & Hedera helix \\
\hline Pinus brutia & Pyracantha coccinea \\
\hline Prunus cerasifera 'Pissardii Nigra' & Pittosporum tobira 'Nana' \\
\hline Picea pungens 'Fat Albert' & Viburnum tinus \\
\hline Cedrus libani & Juniperus horizontalis 'Bar Harbor' \\
\hline \multicolumn{2}{|l|}{ Chamaecyparis lawsoniana } \\
\hline \multicolumn{2}{|l|}{ Thuja occidentalis } \\
\hline \multicolumn{2}{|l|}{ Thuja orientalis 'Aurea Nana' } \\
\hline Thuja orientalis 'Pyramidalis Aurea' & \\
\hline
\end{tabular}

"TYP-3 positioned as an extension of TYP-2" the typology characteristics of which are determined from the perspective of the Bülent Ecevit University 15 Temmuz Şehitler Campus reference point which is also the starting point of the study area in the western direction ends at the Zonguldak 100. Y1l Bus Terminal which is also the eastern boundary of the study area. TYP-3 has 4 lanes with a refuge planted with trees and shrubbery, has a green band with the left side planted with trees. It makes significant contributions to the city of Zonguldak and its environmental aesthetics with regard to central refuge design and roadside plantation. Plant use in the section of the study area entitled as TYP-3 has linearly divided the vehicle road and walkway with only the green band application on the left walkway. It was observed to make positive impacts only in the Bartın-Zonguldak direction when plant use was examined with regard to direction and establishment of a transportation corridor. The use of sporadically frequent 
and sparse shrubbery on the central refuge does not display a consistent positive characteristic for the prevention of headlights from the opposite lane and the reduction of the severity of possible accidents. It also does not have deterrent effects with regard to pedestrian safety when crossing the streets outside pedestrian crossings. The green band application between the vehicle road to the left side of the road and the walkway has also been evaluated positively with regard to pedestrian safety. TYP-3 provides insufficient spatial characteristics for pedestrian comfort as part of streetscape with plantation application in only one of the walkways within the scope of roadside plantation application as one of the important components of streetscape.

The plantation presence in the study area (TYP-1, TYP-2, TYP-3) provides positive contributions to urban ecology by way of improving air quality, creating microclimatic effects, habitat generation, contributions to urban biodiversity, absorbing dust and harmful gases.

It was observed that the plants used in walkways, green bands and refuges have been planted without taking into consideration their maximum crowns and without leaving sufficient area for rooting. The plants are continuously pruned in order to keep them at certain dimensions since there is not sufficient space for proper root and crown growth. This has disrupted the root-stem balance of the plant resulting in negative impacts on plant development as well as the lack of spatial desired effects.

\section{Conclusion and Discussion}

Plant use is important regarding a sensory integration with the space in order for people to perceive and grasp the space they are in. In this regard, plantation applied on roads for the effective shaping of the urban macroform has positive impacts on the characteristics of roads transforming them into more livable spaces. The use of plants on urban roads plays significant roles in establishing the interaction and harmony between nature-city and humans for reducing the spatial perception from the urban to the human scale. Roadside trees used in streetscape applications make positive contributions to urban ecology due to their microclimatic effects in addition to improving air quality, noise control, habitat development, contributing to urban biodiversity, absorbing dust and harmful gases. In this scope, roadside trees have various potential for improving the quality of life.

Urban roadside trees as part of urban landscape are trees that are affected most negatively from the environment. Hence, they require more sensitivity with regard to plant and location selection in comparison with other plantation applications. In this scope, urban road trees should be selected from fruitless species with proper size and form, positioned with consideration to root growth area, that are suitable to the ecological conditions of the region, with high toleration against poisonous gases and dust which can adapt to weather conditions due to the formation of urban heat islands with a root system that will not harm the urban infrastructure.

It is important that the plants selected for refuge plantation do not have a distracting. Plants branching from the ground up that are in accordance with the plants on the walkways and the green band should be used for a certain distance in order to guide the drivers without distracting them while preventing the effects of headlights thus complementing streetscape applications in a functional manner. In addition to aesthetic contributions, it is also of special importance for vehicle and pedestrian safety in addition.

Green band applications and their continuity which are effective for linearly dividing the walkway widths that are important for pedestrian traffic and the vehicle roads are evaluated within the scope of highway landscape planning and design studies for ensuring providing direction and transportation corridor.

Plant use in urban roads within the scope of streetscape applications makes significant contributions to urban ecology, urban aesthetic and urban quality of life. In this regard, the $1.2 \mathrm{~km}$ long route between the Bülent Ecevit University 15 Temmuz Şehitler Campus and 100.Yıl Bus Terminal on the Millli Egemenlik Street as the main artery in the city of Zonguldak should be supported by continuous street plantation works on both sides of the road in order to ensure proper direction and transportation corridor formation. Green band applications that are important for linearly separating the vehicle road and walkway should be continuous and well-kept. Priority should be given to the renewal of the use of shrubbery and trees for refuge arrangements with a consistent and holistic perspective for their contribution to vehicle traffic and pedestrian safety as well as aesthetic concerns. In conclusion, taking into consideration the study area in a holistic manner for strengthening the transportation corridor effect, improving the functional support to vehicle and road traffic effect, increasing pedestrian comfort level and contributions to urban ecology are of special importance for the urban quality of life in Zonguldak and the urban image. 


\section{References}

Aslanboğa, İ. (1986). Kentlerde Yol Ağaçlaması. Tubitak Yayınları, Yapı Araştırma Enstitüsü. Yayın No: U3. Ankara. s:1-54.

Berland, A., Shiflett, S. A., Shuster, W. D., Garmestani, A. S., Goddard, H. C., Herrmann, D. L., Hopton, M. E. (2017). The role of trees in urban stormwater management. Landscape and Urban Planning, 162, 167-177.

Ertin D. G., Meral M. V., Zülfikar C. (2011). Yaya ve taşıt trafiği açısından bitkisel tasarım; Edirne örneği. X. Ulusal Ekoloji ve Çevre Kongresi, Bildiri Özetleri Kitabı. Çanakkale, 4-7 Ekim 2011, ss. 54-55.

Gül A. and Küçük V. (2001). Kentsel açık-yeşil alanlar ve Isparta kenti örneğinde irdelenmesi. Süleyman Demirel Üniversitesi Orman Fakültesi Dergisi, A-2, 27-48.

Karakaya, B. and Zülfikar, C. (2013). Kent içi yolların bitkisel tasarım ilkeleri açısından incelenmesi: Atatürk Bulvarı-Edirne. VIII. Uluslar Arası Sinan Sempozyumu, 25-26 Nisan.

Küçük, V. and Gül, A. (2005). Isparta kent içi yol ağaçlandırmaları üzerine bir araştırma. Süleyman Demirel Üniversitesi Fen Bilimleri Enstitüsü Dergisi, 9 (3), 111-118.

McPherson, E. G. (2003) A benefit-cost analysis of ten street tree species in Modesto, California, U.S. Journal of Arboriculture, 29, 1-8.

Ode, A. (2003). Visual aspects in urban woodland management and planning. Doctoral thesis, Swedish University of Agricultural Sciences, Department of Landscape Planning. Alnarp, Sweden.

Ranta, P., Kesulahti, J., Tanskanen, A., Viljanen, V., Virtanen, T. (2015). Roadside and riverside green-urban corridors in the city of Vantaa, Finland. Urban Ecosystems, 18(2), 341-354.

Sağlık A., Erduran F., Sağlık E. (2012). Bitkisel tasarımın karayolu trafik güvenliğinde önemi: Çanakkale örneği. 3. Karayolu Trafik Güvenliği Sempozyumu, Ankara, Türkiye, 16-18 Mayıs, ss.77-90.

Samara, T. and Tsitsoni, T. (2011) The effects of vegetation on reducing traffic noise from a city ring road. Noise Control Engineering Journal, 59, 68-74.

Tiwary, A., Williams, I. D., Heidrich, O., Namdeo, A., Bandaru, V., Calfapietra, C. (2016). Development of multi-functional streetscape green infrastructureusing a performance index approach. Environmental pollution, 208, 209-220.

Turner-Skoff, J. B. and Cavender, N. (2019). The benefits of trees for livable and sustainable communities. Plants, People, Planet, 1, 323-335.

Yang J, Zhou J, Ke Y, Xiao J (2012) Assessing the structure and stability of street trees in Lhasa, China. Urban Forestry \& Urban Greening, 11, 432- 438.

Yılmaz, F. and Aksoy, Y. (2009). Şehir içi yol bitkilendirmelerinin İstanbul İli Beyoğlu İlçesi Cumhuriyet, Halaskargazi ve Büyükdere Caddesi örneğinde irdelenmesi. Journal of Yaşar University, 4(16), 2699-2728.

Zhou, X., Zhang, L., Zhang, Z. F. (2012). Current status of green space and plant disposition in the urban road landscape design. In Applied Mechanics and Materials, 209, 352-356. 


\section{Internet References}

URL-1 Zonguldak Environmental Status Report (2017), https://webdosya.csb.gov.tr /db/ced/icerikler/zonguldak_2017_cdr-20180917152751.pdf (A. D. 10.11.2019).

URL-2 http://www.cografya.gen.tr/tr/zonguldak/iklim.html (A. D. 10.11.2019)

URL-3 https://tr.climate-data.org/asya/tuerkiye/zonguldak/zonguldak-271/ (A. D. 10.11.2019) 